\title{
COLOSSI-CRUMBS IN THE YEAR 1900 - COLOSSI-COLOSSI IN THE YEAR 2100 TRANSFER OF DEMOGRAPHIC-ECONOMIC PREDOMINANCE FROM EURASIA TO AFROAMERICA
}

\author{
Luca DIACONESCU * \\ University of Oradea, Doctoral School of geography, 1st, Universității St., 410087, Oradea, Romania, \\ e-mail: diaconesculuca@yahoo.ro \\ Nicolae NICHITUT \\ Professor of history and geography at the Gherta Mica Secondary School, Scolii St., Nr. 6, 447140, \\ Satu Mare, Romania, e-mail: nicunichitut@yahoo.com
}

\section{Mădălin-Sebastian LUNG}

Ph.D. Student, Babeș-Bolyai University, Faculty of Geography, Clinicilor Street, Nr. 5-7, RO- 400006, Cluj-Napoca, Romania, e-mail: 1ungmadalin@yahoo.com

\begin{abstract}
Citation: Diaconescu, L., Nichitut, N., \& Lung, M.S, (2019). Colossi-Crumbs in the Year 1900 - Colossi-Colossi in the Year 2100 Transfer of Demographic-Economic Predominance from Eurasia to Afroamerica. Revista Română de Geografie Politică, 21(2), 50-59. https://doi.org/10.30892/rrgp.212103-328
\end{abstract}

\begin{abstract}
If in 1900 Eurasia was the mistress of the world and Afroamerica only its crumbs, by the year 2100 the two major regions will be on an equal footing, becoming two colossi with roughly equal proportions of demography, economy, influence and culture. The new geopolitical atmosphere of the world is mainly due to the planetary demographic modeling and its distribution across the continents, so in the 1800s and 1900s Afroamerica held only $12 \%$ and $16 \%$ of the world's population, reaching $30 \%$ in 2019 and over $50 \% 2100$, when it will most likely surpass the Eurasia demographic power, creating new major demographic, economic, cultural and major trade routes, not existing in the 1900 s or 2000 s.
\end{abstract}

Key words: geopolitics, population, demographic explosion, power, empires

\section{INTRODUCTION}

Everyone agrees that the surface of the planet is in a fierce modeling, a phenomenon due almost entirely to the multiplication of the human race and its behavioral change. Scientific progress has brought us new heights of civilization, following which the human race has entered into an explosive demographic growth with drastic consequences on the environment but also with additional pressure put 
on the forced economic modernization leading to industrial- increasing agricultural competitiveness. This continuous progress acts as a stimulus to the masses of people, increasing the general well-being of the inhabitants of the planet, manifested both by economic development in some parts of the planet and by re-accelerating the demographic growth creating new and overpopulated areas, which changes decisively and over extended periods, planetary geopolitics.

Whenever a continent, an empire, a country, or a small territory had significant population, it tended to influence, colonize and culturalize the less populated territories, becoming directly or indirectly their masters. In the last millennium, the great empires that dominated the world came from Asia and Europe, colonizing and conquering territories of Africa and America, christianizing them or islamizing to them. Also within these continents, the demographic predominance of empires has also given the tone of power.

Europe has succeeded in dominating the world through economic power over the great Asian demographic power, especially as Europe as a whole, overwhelmed the Asian subcontinent population such as East Asia or South Asia, these creating different worlds due in particular to the rugged relief of of the Himalayan mountains separating them.

During this time, Africa and America have lost their identity, becoming the vassals of the former, as follows: Islamo-Christianization, the languages: Arabic, English, Portuguese, Spanish, French, Dutch, German, Italian etc., Euro-Asian culture or slavery, were introduced into Afroamerica as an outlet and exploitation market in which Europeans and Asians came as masters and Africans or Americans were leaving the two continents as slaves sold. But this what it seemed eternal past has lost its topicality, Eurasia has lost its influence and Afroamerica has been returning to the masses of the great civilizations for many hundreds of years, having a growing importance that will grow throughout the $21^{\text {st }}$ century and beyond, a late demographic and economic hub of the planet, moving from the status of the Eurasian colossus, to the status of colossus with equal rights, power and ambitions. Among the main reasons for the misappropriation of the old world order, perhaps the most important is the demography of the two mega-regions, being the main element in the distribution of the current and future redistribution of power on Earth.

\section{THE DOMINANT DEMOGRAPHIC TRENDS OF THE WORLD}

There are many geographic and human phenomena that radically shape the world in which we live, from: religion, independent states, territories, organizations, economy, technology, alliances, resources or urbanization, but between them the evolution of the population radically changes the whole geopolitics of the world, attracting redistribution all other economic and geographic features. The most influential demographic changes in the past and the future globally, we identified them as follows:

- the first major change at the planetary level is the demographic explosion of 1.7 billion inhabitants more than 2000 by 2020, just as the total population of the world in 1900. Only in the past 70 years, besides the 2, 5 billion inhabitants on the planet in 1950 when World War II was just over, Communism had begun to expand into Eastern Europe, the Berlin Wall had not been built, the European Union had not emerged, China was wrestling in poverty, Japan was devastated of war, and Africa was still dominated by colonialism, a year that many of those who live today they caught him, and in which it seemed that the world had reached the 
maximum of overpopulation of the planet. After just 7 decades, the population triple on Terra, rising by more than 5 billion people, creating a totally different world as a demographic dimension compared to that year. To this, another 2.5 billion can be added in just 30 years, as it is expected to increase the population of the planet by 2050, ie more than three times the population of Europe or as they are: Europe, America and Oceania now plus all Arab states, Russia and Japan together. By the year 2100, another at least 1.5 to 3.0 billion people are expected to be on the earth in the 50 years (Diaconescu, 2016);

- the second major demographic modeling of geography known in 1900 is the displacement of the planetary demographic center to the south. If we divide the surface of the land into two roughly equal halves, except Antarctica, we will see that the northern half dominated by the largest economic powers, developed areas and the civilized power that existed over the last four centuries, consisting of: Europe, Russia, USA and Canada, Asia Minor, Central Asia and East Asia, he held during world economic preeminence and demographic predominance, with $62 \%$ of the world's population. In 1950, the southern half composed of: Latin America, Africa, Oceania, South-South, South and South-East Asia reached for the first time after 400 years $50 \%$ of the world's total population and in 2000 to 62 $\%$, with in 2050 going to be $70 \%$ and in 2.100 for $80 \%$ of the world's total population, when the northern half will only have $20 \%$. The current migration of the southern population to the north such as the Spaniards towards the US and Canada, Africans and Arabs towards Europe, the immigration crisis, the economic crises that increasingly hit the north, the loss of global pre-eminence and the economic and financial transfer to the south are consequences of modeling demographic, being just a phenomenon just beginning, the south exporting immigrants and culture and attracting wealth and technology from the north (Diaconescu, 2017);

- the third major change is dominated by the geopolitics of the oceans, these through the commercial-economic value, leading to the rise or fall of the powers that surround them. Prior to 1500 , the dominant maritime trade on Terra was in the Indian Ocean, followed by the Atlantic, and after 450 years of domination, it began to give way to the Pacific in 1950. These changes coincide with the population around these oceans, so the larger population of the world has been around the oceans as was the commercial preeminence. After 1950, the population around the Pacific Ocean became the largest population bypassing the people around the Atlantic Ocean, with the population around the Indian Ocean ranked third. According to this theory, by repeating history, the most populous population has now become around the Indian Ocean, which already has 3.0 billion inhabitants, followed by the Pacific Ocean population of 2.2 billion and the Atlantic Ocean with 1.8 billion inhabitants. The population around the Indian Ocean is in a colossal demographic explosion, estimated to reach $40 \%$ of the world's population around it with 3.6 billion inhabitants in 2050 and $50 \%$ of the world's population in 2100 with 4.4 billion people. Thus, the great maritime and economic powers are expected to be around this ocean and the states outside the established area face an economic downturn similar to Europe at present (or the transfer of US power from the Atlantic coast to the Pacific coast or Russia, from European Russia to Asian Russia) following the economic and commercial transfer from the Atlantic to the Pacific (Diaconescu, 2018a);

- the fourth major change is the transfer of demographic and inevitable and economic primacy from Europe and Asia dominating in 1900 with $81 \%$ of the 
world's population into Africa and America that already have $30 \%$ of the world's population and up to $52 \%$ of the world's population by the year 2100 , a phenomenon that will continue after this year, and which, together with the other three great demographic miracles, will create a whole new world with new, demographic, economic and dominant commercial routes which not existed in 1900 , or in 2000 .

\section{DEMOGRAPHIC DISTRIBUTION AROUND 1900}

Not long before the First World War, the world's population was significant for that time, reaching 1.7 billion inhabitants, from less than one billion as it existed in 1800, and experts considered the demographic explosion was exaggerated for the power of support of the planet. The first mega-city with over 5 million inhabitants appears, London in Europe being considered then a colossal metropolis (At the level of 1900 there are only three cities with more than 3 million inhabitants: London 6.5 million, New York 4.0 million and Paris by 3.0 million, while at the level of 2019 there are over 160 cities that together with the urban agglomeration exceed 5 million inhabitants) (Diaconescu and Lung, 2018; Bonnet, 2000; M.C.M.X.C., 1990).

At that time, Europe had become overpopulated being on the brink of war for territorial redeployment, and Asia continent was the only very little colonized with great global influence, due in particular to its demographic and cultural power, with a double population of to Europe (Grumaz, 2013; Zakaria, 2009; Pedrero, 2008).

During this time, Africa was divided between the economic powers of Europe and America was beginning to gain the independence, under the leadership of emigrated Europeans in Europe, what they had brought along, including culture, religion, lifestyle and industrialization (Bessis, 2004; Diaconescu, 2018b).

The demographic and economic picture of the planet was dictated by the distribution of the population, so most of it was in the north-east, Asia (950 million inhabitants) and Europe (430 million inhabitants), with $81 \%$ of the total population, while the southeast of Africa (120 million inhabitants) and America (150 million inhabitants) held only $16 \%$.

\section{PLANETARY DEMOGRAPHIC REDEPLOYMENT BETWEEN 1900 AND 2000}

After 1900, the population of Europe is starting to stagnate, the demographic momentum in Asia remains at the same rates, Africa is starting to recover demographically, and America, especially due to immigration, is witnessing a demographic explosion. Until 1950, Europe and Asia have grown from 1,380 million to 81 percent of the world's population, to 1,950 million to 77 percent of the world's population, while Africa and America are developing from 270 million and 16 percent of the world's population, to 560 million and $22 \%$ of the world's population.

By the year 2000, the demographic shift is even more pronounced, Europe is stagnating demographically, Asia reduces its demographic footprint, America is also declining slightly as the demographic gallop begins, leaving Europe and Asia to hold only $72 \%$ of the world's population by 4,430 million of the population, while Africa and America grow to $27 \%$ of the world's population with 1,640 million inhabitants. As a major consequence, African states gain most of their independence (Herman and Grama, 2018). 
After another 50 years, the population of Europe and Asia will hold $61 \%$ of the world's total population with 5.980 million inhabitants, while Africa and America will account for 38\% of the world's population with 3.735 million inhabitants, next in the year 2100, after another 50 years, Europe and Asia will have half of the world's population, while Africa and the Americas will also be halved, with populations ranging between 5,300 million and 6,800 million inhabitants. Depending on demographic forecasts, there is a clear trend of demographic overflow of the large Eurasia region by Afroamerica.

Table 1. Evolution of population by large geographic regions, in millions of inhabitants: Eurasia and Afroamerica, between 1800 and 2100

Source: Basten et al., 2013; Lutz, 2008; Lutz and Samir, 2010; International Institute for Applied Systems Analysis, 2004; United Nations, 2004, 1998.

\begin{tabular}{|c|c|c|c|c|c|c|c|}
\hline Regions & 1800 & 1900 & 1950 & 2000 & 2019 & 2050 & 2100 \\
\hline EURASIA & $\mathbf{8 2 0}$ & $\mathbf{1 . 3 8 0}$ & $\mathbf{1 . 9 5 0}$ & $\mathbf{4 . 4 3 0}$ & $\mathbf{5 . 3 4 0}$ & $\mathbf{5 . 9 8 0}$ & $\mathbf{5 . 3 0 0 - 6 . 2 0 0}$ \\
$\mathbf{5 4 , 7}$ million km $^{\mathbf{2}}$ & $\mathbf{8 2} \%$ & $\mathbf{8 1} \%$ & $\mathbf{7 7 \%}$ & $\mathbf{7 2 \%}$ & $\mathbf{6 9} \%$ & $\mathbf{6 1 \%}$ & $\mathbf{4 9 - 4 8 \%}$ \\
\hline Europe & 200 & 430 & 550 & 730 & 740 & 720 & $600-700$ \\
\hline Asia & 620 & 950 & 1.400 & 3.700 & 4.600 & 5.260 & $4.700-5.500$ \\
\hline AFROAMERICA & $\mathbf{1 2 0}$ & $\mathbf{2 7 0}$ & $\mathbf{5 6 0}$ & $\mathbf{1 . 6 4 0}$ & $\mathbf{2 . 3 4 5}$ & $\mathbf{3 . 7 3 5}$ & $\mathbf{5 . 4 0 0 - 6 . 8 0 0}$ \\
$\mathbf{7 2 , 9}$ million km & $\mathbf{5 0 - 5 2} \%$ \\
\hline America & $\mathbf{1 2} \%$ & $\mathbf{1 6 \%}$ & $\mathbf{2 2 \%}$ & $\mathbf{2 7 \%}$ & $\mathbf{3 0 \%}$ & $\mathbf{3 8 \%}$ & $\mathbf{5 0 - 5}$ \\
\hline Africa & 30 & 150 & 340 & 840 & 1.025 & 1.215 & $1.100-1.300$ \\
\hline Terra & 90 & 120 & 220 & 800 & 1.320 & 2.520 & $4.300-5.500$ \\
\hline & 990 & 1.700 & 2.500 & 6.060 & 7.700 & 9.700 & $\begin{array}{c}10.700- \\
13.000\end{array}$ \\
\hline
\end{tabular}

Between 1900 and 2100, among countries with over 100 million inhabitants who can represent the main cultures, economies, influence and source of population migration, there is an increasing number of them in the Africa-America perimeter. In 1900, there were only 3 states with more than 100 million inhabitants, all of them in Eurasia, climbing to 4 states in 1950 with 3 in Eurasia and one in Afroamerica and 11 in 2000, with 7 in Eurasia and 4 in Afroamerica. Currently, they have risen to 14, of which 8 in Eurasia and 6 in Africa, and by 2050 to expect an estimated 19 to 22 states to exceed this high threshold, 9-12 in Eurasia and 10 in Afroamerica. Although Afroamerica will have only $38 \%$ of the world's population, the equal number of states with over 100 million is due largely to the large number of African states. Until 2100, from only 14 states with more than 100 million inhabitants are currently (no European country not part of this ranking except Russia, only Germany approaching 82 million inhabitants, France with 65, Britain with 63 or Italy with 60 million) will reach an estimated 23 to 42 states, of which 9 to 17 will be in Eurasia and 14 to 25 in Afroamerica, being a year too distant for a low-margin forecast. It is certain that Africa will become the support of most states with over 100 million inhabitants, the number of them reaching 22, while Europe will have at most Russia that will exceed this demographic threshold.

These major changes since 1900 to date have influenced the world's perception of both old coloss such as Europe and Asia, but especially the continents that could be considered almost empty of the population into the past. If in 1900 Africa and America alone held only half of the continent's population of Europe on a seven-fold area bigger, in Afroamerica's presence it has three times as much and by 2050 it will have more than 5 times the population and $8-10$ times more in the year 2100 . 
It is meant to jeopardize the idea of Europe's world leader, the decrease of Asian influence and the growing interest of the general interest for Africa and America (Dobrescu, 2008, 2016; Toffler and Toffler, 1995; Kaplan, 2015).

Table 2. The number of states with over 100 million inhabitants and their distribution to the larger regions: Eurasia and Afroamerica between 1900 and 2100

Source: Diaconescu, 2016; Atlas of World History, 2009; Worldometers 2019; Haack, 1989; Gardner and Berenson, 1989; Meinhardt and Schafer, 1996; Neguț, 2011

\begin{tabular}{|c|c|c|c|}
\hline Year & $\begin{array}{l}\text { Total states } \\
\text { with over } 100 \\
\text { million } \\
\text { inhabitants }\end{array}$ & $\begin{array}{c}\text { EURASIA } \\
\text { (no. of states with over } 100 \text { million } \\
\text { inhabitants and their ranking - } \\
\text { millions inhabitants) }\end{array}$ & AFROAMERICA \\
\hline 1900 & 3 & $\begin{array}{l}\text { China } 410 \\
\text { India } 290 \\
\text { Russia } 136\end{array}$ & 0 \\
\hline 1950 & 4 & $\begin{array}{l}\text { China } 560 \\
\text { India } 370 \\
\text { Russia } 100\end{array}$ & USA $150^{1}$ \\
\hline 2000 & 11 & $\begin{array}{l} \\
\text { China } 1.240 \\
\text { India } 1.040 \\
\text { Indonesia } 205 \\
\text { Russia } 147 \\
\text { Pakistan } 140 \\
\text { Bangladesh } 130 \\
\text { Japan } 127\end{array}$ & $\begin{array}{l}\text { USA } 280 \\
\text { Brazil } 170 \\
\text { Nigeria } 110 \\
\text { Mexic } 101\end{array}$ \\
\hline 2019 & 14 & $\begin{array}{l}\text { China } 1.420 \\
\text { India } 1.365 \\
\text { Indonesia } 268 \\
\text { Pakistan } 203 \\
\text { Bangladesh } 167 \\
\text { Russia } 143 \\
\text { Japan } 126 \\
\text { Philippines } 107 \\
\end{array}$ & $\begin{array}{l}\text { USA } 328 \\
\text { Brazil } 212 \\
\text { Nigeria } 200 \\
\text { Mexic } 132 \\
\text { Ethiopia } 109 \\
\text { Egipt } 100\end{array}$ \\
\hline 2050 & $19-22$ & $\begin{array}{l}\text { 9-12 } \\
\text { India 1.600-1.850 } \\
\text { China 1.400-1.550 } \\
\text { Pakistan 300-380 } \\
\text { Indonesia 310-360 } \\
\text { Bangladesh } 210-250 \\
\text { Philippines } 150-170 \\
\text { Russia 110-130 } \\
\text { Vietnam 110-130 } \\
\text { Japan 100-115 } \\
\text { Turkey 90-100 } \\
\text { Iran 90-100 } \\
\text { Yemen 90-100 }\end{array}$ & \begin{tabular}{l}
\multicolumn{1}{c}{10} \\
Nigeria 380-460 \\
USA 370-450 \\
Ethiopia 230-270 \\
Brazil 230-260 \\
Congo 210-250 \\
Mexico 160-170 \\
Egypt 130-170 \\
Tanzania $120-150$ \\
Kenya 100-130 \\
Uganda $100-130$
\end{tabular} \\
\hline 2100 & $23-42$ & $\begin{array}{l}\text { India } 1.800-2.700 \\
\text { China } 950-1.600\end{array}$ & \begin{tabular}{l}
\multicolumn{1}{c}{$14-25$} \\
Nigeria $700-900$ \\
USA 450-550
\end{tabular} \\
\hline
\end{tabular}




\begin{tabular}{|l|l|l|}
\hline & Pakistan 300-450 & Congo 280-450 \\
& Indonesia 300-420 & Ethiopia 260-400 \\
& Bangladesh 180-260 & Tanzania 280-350 \\
& Philippines 180-250 & Brazil 180-280 \\
& Iraq 140-200 & Uganda 170-270 \\
& Afghanistan 100-140 & Egypt 130-240 \\
& Yemen 100-130 & Kenya 160-230 \\
& Vietnam 80-130 & Niger 140-220 \\
& Iran 80-130 & Mexico 130-200 \\
& Turkey 80-130 & Zambia 100-140 \\
& Russia 100-120 & Malawi 100-140 \\
& Japan 80-100 & Mali 80-140 \\
& Thailand 60-100 & Angola 70-140 \\
& Saudi Arabia 60-100 & Sudan 120-130 \\
& Malaysia 60-100 & Burkina Faso 90-130 \\
& & Mozambique 70-130 \\
& & Madagascar 90-120 \\
& & Ivory Coast 80-100 \\
& & Ghana 70-100 \\
& & Somalia 70-100 \\
& & Cameroon 70-100 \\
& & South Africa 60-100 \\
& & Senegal 60-100 \\
\hline
\end{tabular}

\section{YEAR 2100, AFRICA AND AMERICA OVERTAKE THE POPULATION OF EUROPE AND ASIA}

In 2100 , the planetary demographic distribution is completely new to what was known in 2000, and unimaginable for the year 1900. Old Western crumbs in terms of economic, demographic or agricultural power become colossal, while the old colossians are now as an equal footing with their former colonies and the support of their own emigrants.

In 1900, China had a population as much as the continent of Europe but four times as much as the continent of Africa. At present, it has reached a population twice that of the continent Europe but equal with the population of Africa, and by the year 2100 , the Chinese population will be twice as large as the population of Europe, but will be overtaken by Africa four times.

If in 1900 Nigeria had a population of only 16 million inhabitants, which was slightly more than twice the London population at that time and under $4 \%$ of Europe's population, so far the African state already has a population equal to that of Germany, Italy and Britain together while the main city of Lagos exceeds the population of London by at least 50\%, and by 2100 Nigeria will have a larger population than the whole of Europe, and Lagos as a city will exceed the population of Germany. Also, Russia will have about the same population in the 1900 s as in 2100, about 110-140 million inhabitants, while the population of the Ethiopian and Congo states will grow from just 4 million inhabitants each (6.5 millions of inhabitants were the population of Romania at that time), are expected to increase by 2100 to over 400 million people for each (approximately 15 million inhabitants expect to own Romania) (Staşac, 2009; Attili, 2016; Friedman, 2009; Erdeli and Cucu, 2007; Gaceu, 2007; Ilieș, 2006; Muntele and Raluca, 2010).

Changes may be even more relevant to the population of cities in the two major land areas of the Earth. If in 1900 the large cities of Eurasia had populations as whole states in Afroamerica, until 2100, the situation would be 
reversed. At 1900, the city of Paris had a population of 3 million, that is, a population equal to the state of Peru in America or the States: Angola, Mozambique or Madagascar, and almost double the population of Kenya and three times the Malawi from Africa. Until 2100, the population of Paris will most likely have a population of between 10 and 20 million inhabitants, while Peru's population will exceed 50 million, the state of Kenya will exceed 200 million and the other states will each exceed 100 million inhabitants, while in each of them there will be at least one city that will exceed the population of Paris (Lima), or even more than 4-8 times (Nairobi, Luanda, Maputo, Magadiscio, Blantyre or Lilongwe).

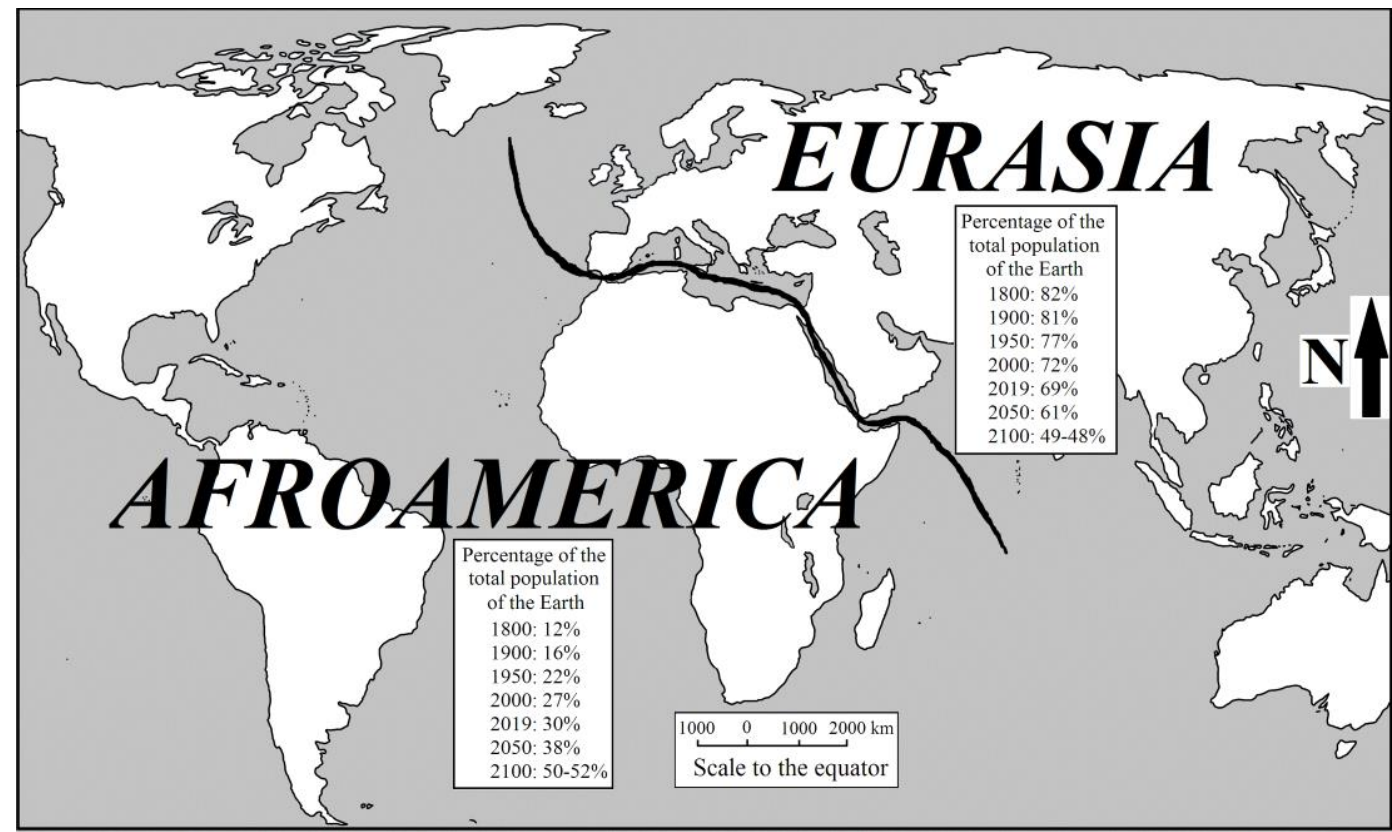

Figure 1. Evolution of the population of the large Eurasian and Afroamerica regions of the world's total population between 1800 and 2100

Source: Basten et al. 2008; Lutz and Samir, 2010; International Institute for Applied Systems Analysis, 2004; United Nations, 2004, 1998; Drago et. al., 1995.

\section{AFTER 2100. THE TRANSFER OF DEMOGRAPHIC PREDOMINANCE BRINGS WITH IT THE ECONOMIC TRANSFER}

Even after 2100, the world demographic trend will still be in favor of Afroamerica, whose population will continue to grow rapidly, with more and more percentages of the world's population at the expense of Eurasia, most likely by 2150 , to $55-60 \%$ of the world's total population.

As demonstrated throughout history, large demographic concentrations have attracted the world's wealth, becoming new planetary economic centers, to the detriment of regions that have diminished demographic explosion. Compared to 1900 when Europe surpassed America's economic strength several times, in 2019, America's \$ with 28 trillion surpassed the continent of Europe with an economic power of 22 trillion US dollars (Peptenatu et. al., 2005; Negut et. al., 2009; Toffler, 1995). Until 2100, only North America expects to exceed with 50\% the economic power in Europe, and Central and South America along with the 
newly industrialized Africa to begin approaching and even overtaking the Asian economic power. South America will most likely become the world's agricultural power, North America will be the main territory of exploiting natural resources and technological power and Africa will become the world's new atelier as a great industrial power.

\section{CONCLUSIONS}

If Europe and Asia represented the human and economic geography of the planet in 1900, during which Africa and America, continents without demographic power, obviously economic, without prestige, culture, influence or national dignity, being basically crumbs of the world that count, until 2100, Eurasia loses total demography and obviously in economy, culture and influence, being on an equal footing with its old playground, Afroamerica.

\section{REFERENCES}

Attili, J. (2016). Scurtă istorie a viitorului (Brief history of the future), Editura Polirom, București. Bessis, S. (2004). Occidentul și ceilalți (The West and the others), Editura Runa, București.

Bonnet, J. (2000). Marile Metropole Mondiale (Great World Metropolises), Editura Institutului European, Iaşi.

Diaconescu, L. (2017). Global Competition Between North and South. Revista Română de Geografie Politică, 19(2), 103-115.

Diaconescu, L. (2018a). Geopolitics of the Oceans: The Demographic Influence in the Separation of Powers. Revista Română de Geografie Politică, 20(2), 75-85.

Diaconescu, L. (2018b). The development center and the progress of the World history and perspectives, Revista Română de Geografie Politică, 20(1), 30-35.

Diaconescu, L. (2016). Cities versus states: demographic evolution, Geographica Timisiensis, 25(1).

Diaconescu, L. \& Lung, M.S. (2018). Power of big cities. Revista Română de Geografie Politică, 20(2), 67-74.

Dobrescu, P. (2008). Geopolitica, Editura Comunicare.ro, București.

Dobrescu, P. (2016). Crizele de după criză. O lume fără busolă și fără hegemon (Crisis after crisis. A world without a compass and no hegemon), Editura Litera, București.

Drago, M., Boroli, A., Boroli, P., Motta, G., \& Bernardini, E. (1995). Grande Atlante del Mondo, Editura Instituto Geografico de Agostini, Novara, Italia.

Erdeli, G., \& Cucu, V. (2007). România: populație, așezări umane, economie (Romania: population, human settlements, economy), Editura Transversal, București.

Friedman, G. (2009). Următorii 100 de ani: previziuni pentru secolul XXI (The next 100 years: predictions for the $21^{\text {st }}$ century), Editura Litera, București.

Gaceu, O. (2007). Asia, Oceania și Australia, Editura Universității din Oradea, Oradea.

Gardner, J.L., \& Berenson, R.J. (1989). Atlas of the World, Editura Reader,s Digest, Londra, Marea Britanie.

Grumaz, A. (2013). Al Treilea Război Mondial (World War III), Editura Rao, București.

Haack, H.V. (1989). Atlas fur jedermann (Atlas for everyone), Editura Kartographische Anstalt Gotha, (Germania de Est) Germania.

Herman, G.V., \& Grama, V. (2018). Geographical aspects of space-time evolution of independent states. Revista Română de Geografie Politică, 20(2), 49-56.

Ilieș, A. (2006). Elemente de geografie politică: Spațiul european (Elements of Politica Geography: European Space), Editura Universității din Oradea, Oradea.

Kaplan, D.R. (2015). Răzbunarea geografiei: ce ne spune harta despre conflictele viitoare și lupta impotriva destinului (Revenge of geography: what the map tells us about future conflicts and fight against destiny), Editura Litera, București.

Meinhardt D., \& Schafer E. (1996). Unsere Welt: Der Atlas fur die ganze Familie, RV Verlag, (World: The Atlas for the whole family, RV Verlag), Stuttgart, Germany.

Muntele, I., \& Raluca, H.Ș. (2010). The contradicțions of the relaunching of the population fertility indicators in contemporany Europe. Analele Universității din Oradea, Seria geografie, 20(1), 76-85.

M.C.M.X.C. (1990). Grand Atlas Geographique et Encyclopedique, Editura Instituto Geografico De Agostini, Paris, Franța.

Neguț, S., Vlăsceanu, G., Bran, F., Popescu, C., Vlad, L.B., \& Neacșu C.M. (2009). Geografie 
Economică Mondială (Economic Geography World), Editura Meteor Press, București, România. Neguț, S. (2011). Geografie umană (Human Geography), Editura Academiei Române, București.

Pedrero, M. (2008). Corupția marilor puteri: strategii și minciuni în politica mondială (Corruption of Great Powers: Strategies and Lies in Global Politics), Editura Litera, București.

Peptenatu, D., Drăghici, C., \& Cepoiu, L.A. (2005). Geografie economică mondială, Ediția a II-a (World Economic Geography, $2^{\text {nd }}$ Edition II), Editura Universitară, București.

Staşac, M. (2009). Aspects of the Phenomenon of Demographic Population Aging in Romania and the Republic of Moldava in the Context of the European Union Perspective. Revista Română de Geografie Politică, 21(1), 58-64.

Basten, S., Lutz, W., \& Scherbov, S. (2013). Very long range global population scenarios to 2300 and the implications of sustained low fertility. Demographic Research, 28(39), 1145-1166.

Toffler, A. (1995). Puterea în misscare: cunoașterea, bogătia și violența în pragul secolului XXI (Power in motion: knowledge, wealth and violence at the threshold of the 21st century), Editura Antet, București.

Toffler, A., \& Toffler, H. (1995). A crea o nouă civilizație (Create a new civilization), Editura Imprimeria de Vest, Oradea.

Lutz, W., \& Scherbov, S. (2008). Exploratory extension of IIASA's world population projections: scenarios to 2300, International Institute for Applied Systems Analysis, Austria.

Lutz W., \& Samir K.C. (2010). Dimensions of global population projections: what do we know about future population trends and structures?, Philosophical Transactions of the Royal Society B: Biological Sciences, 365(1554), 2779-2791.

Zakaria, F. (2009). Lumea postamericană (The post-American world), Editura Polirom, Iași.

*** (2004). World Population to 2300, International Institute for Applied Systems Analysis.

*** (2009). Atlas de Istorie a Lumii (Atlas of World History) / Instituto Geografico de Agostini, EdituraRao, București.

https://www.un.org/en/development/desa/population/publications/pdf/trends/WorldPop2300fina 1.pdf, United Nations (2004), World Population to 2300, Departament of economic and Social Affairs, Population Division, New York.

https://www.jstor.org/stable/2808146, United Nations (1998), United Nations World Population Projections to 2150, The Population Division of the United Nations Secretariat, Population and Development Review, Vol. 24, No. 1 (Mar., 1998), pp. 183-189.

Worldometers, real time world statistics: www.worldometers.info, last accessed, February, 2019.

Submitted:

March 12, 2019
Revised:

July 22, 2019
Accepted and published online: October 23, 2019 